\title{
Analisis Impor Propinsi Sumatera Utara
}

\author{
Dewi Mahrani Rangkuty ${ }^{1}$ \\ Anwar Sanusi² \\ Dosen Fakultas Ekonomi dan Bisnis Universitas Pembangunan Panca Budi \\ Jalan Jend. Gatot Subroto Km. 4,5 Sei Sikambing 20122, Medan, Indonesia \\ e-mail :dewimahrani@dosen.pancabudi.ac.id ${ }^{1}$
}

\begin{abstract}
ABSTRAK
Penelitian ini bertujuan untuk menganalisis Impor di Provinsi Sumatera Utara dengan metode kausalitas dan kointegrasi antara Impor, PDRB Sumatera Utara, Kurs dan Inflasi selama kurun waktu 1990-2015 pada hubungan keseimbangan jangka pendek dan jangka panjang. Hasil penelitian pada uji kausalitas bahwa PDRB Sumatera Utara menunjukkan hubungan kausalitas dua arah terhadap Impor Sumatera Utara. Artinya Impor Provinsi Sumatera Utara menyebabkan PDRB Sumatera Utara da begitu pula sebaliknya PDRB Sumatera Utara menyebabkan Impor Sumatera Utara. Hasil uji kointegrasi dan koreksi kesalahan Error Corroection Model menunjukkan bahwa PDRB Sumatera Utara secara positif dan signifikan mempengaruhi perubahan Impor di Provinsi Sumatera Utara selama kurun waktu 1990-2015. Sedangkan variabel inflasi dan kurs menunjukkan hubungan kausalitas satu arah terhadap Impor Sumatera Utara. Kepada Pemerintah Provinsi Sumatera Utara melalui regulasinya diharapkan dapat membatasi produk-produk impor Sumatera Utara. Nilai PDRB Sumatera Utara yang tinggi dapat meningkatkan aktivitas ekonomi seperti pembiayaan pembangunan lokal. Sumatera Utara tetap membutuhkan produk impor bagi sumber daya yang tidak bisa dihasilkan namun tidak membawa pada kebergantungan. Sehingga fokus utama Sumatera Utara dalam hal ini menjaga nilai impor setiap periode agar tidak mengganggu pergerakan nilai PDRB Sumatera Utara.
\end{abstract}

Kata Kunci : Impor, PDRB, Kurs, Inflasi 


\title{
Analysis of Import of North Sumatera Province
}

\begin{abstract}
This research aimed to analyze Import North Sumatera for causality and cointegration method between Import, GDRP North Sumatera, Exchange rate and inflation during the period 1990-2015 for short and long term equilibrium relationship. From the results of causality test indicate GDRP North Sumatera had two way causality to Import North Sumatera. Import cause of GDRP North Sumatera and otherwise GDRP cause of Import North Sumatera. Cointegration test and Error Correction Mechanism indicate GDRP North Sumatera as positively and significant influence Import for short and long term equilibrium relationship for during the period 19902015. Whereas exchange rate and inflation had one way causality to Import North Sumatera. To Indonesia Government regulation hopely can control import product especially North Sumatera. High GDRP North Sumatera value can used to increasing other activities economic like development financing local. We need import but no dependency, import cause for resources not available in domestic or local. The Indonesia oriented sure keep on the import value every year of time for high GDRP value.
\end{abstract}

Keywords : Import, GDRP, Exchange Rate, Inflation

\section{PENDAHULUAN}

Sumatera Utara merupakan salah satu provinsi terbesar di Indonesia dan merupakan wilayah terluas di pulau Sumatera Indonesia. Indonesia yang menganut sistem perekonomian terbuka mendorong setiap provinsi di beberapa pulau besar turut serta membangun perekonomian melalui perdagangan internasional baik ekspor maupun impor. Kegiatan ekspor dapat mendukung kelancaran pertumbuhan ekonomi Indonesia sebagai salah satu upaya memenuhi perjanjian dalam perdagangan dunia. Begitu halnya dengan impor, kegiatan impor dilakukan sebagai upaya membantu negara-negara dunia dalam memperkenalkan produk-produknya di pasar internasional, sebab masing-masing negara berbeda potensi dan sumber daya.

Kegiatan impor Provinsi Sumatera Utara menurut kelompok barang ekonomi dapat berupa barang modal, bahan baku/penolong dan barang konsumsi. Menurut sektor dapat berupa minyak dan gas bumi, pertanian, pertambangan dan penggalian, industri dan lainnya (BPS Provinsi Sumatera Utara, 2016). 
Standard International Trade Classification (SITC) adalah sistem penggolongan produk yang dikembangkan pada tahun 1962 oleh Perserikatan Bangsa-Bangsa (PBB). SITC dibuat dengan tujuan untuk mengklasifikasikan produk yang diperdagangkan tidak hanya didasarkan atas sifat material dan fisik produk tetapi juga sesuai dengan tahap pengolahan serta fungsi ekonomi produk tersebut dalam rangka memfasilitasi analisis ekonomi. SITC terfokus pada fungsi ekonomi produk pada berbagai tahap pengolahan. Penggolongan produk menurut SITC mencerminkan : (1) bahan produksi, (2) tahap pengolahan produk, (3) penggunaan produk pada pasar, (4) pentingnya produk dalam perdagangan dunia, dan (5) perubahan teknologi. Dalam kegiatan ekspor dan impor, SITC diterapkan pada ekspor nonmigas menurut kelompok barang dan impor komoditas nonmigas utama (Macroeconomic Dashboard FEB UGM, 2017).

Impor Provinsi Sumatera Utara menurut komoditi 1 dijit SITC dapat berupa bahan makanan dan binatang hidup, minuman dan tembakau, bahan baku, bahan bakar dan sebagainya, minyak/lemak nabati dan hewani, bahan kimia, barang hasil industri, mesin dan alat pengangkutan, hasil industri lainnya, barang dan transaksi khusus lainnya.

Sedangkan impor Provinsi Sumatera Utara menurut komoditi utama 3 dijit SITC dapat berupa hasil-hasil minyak bumi, makanan ternak, pupuk buatan pabrik, bijih aluminium, jagung, polimer dari etilena, biji dan buah mengandung minyak; berkulit lunak, sisa hasil minyak bumi, antiseptik; insektisida; fungisida, mesin pembuat makanan dan suku cadang, dan lainnya (BPS Provinsi Sumatera Utara, 2016).

\section{Tabel 1}

Nilai Impor Menurut Negara Asal Utama (000 US\$) dan PDRB Sumatera Utara (Juta Rupiah), Tahun 2011-2015

\begin{tabular}{|c|c|c|c|c|}
\hline Tahun & $\begin{array}{c}\text { Impor Sumatera } \\
\text { Utara }\end{array}$ & $\begin{array}{c}\text { Laju } \\
\text { Pert. (\%) }\end{array}$ & $\begin{array}{c}\text { PDRB Sumatera } \\
\text { Utara }\end{array}$ & $\begin{array}{c}\text { Laju Pert. } \\
(\%)\end{array}$ \\
\hline 2011 & 4.953 .462 & - & $353.147 .591,20$ & - \\
\hline 2012 & 5.164 .750 & 4,27 & $375.924 .139,45$ & 6,45 \\
\hline 2013 & 5.108 .512 & $-1,09$ & $398.727 .142,80$ & 6,07 \\
\hline 2014 & 5.046 .514 & $-1,21$ & $419.573 .308,67$ & 5,23 \\
\hline 2015 & 3.988 .440 & $-20,97$ & $440.955 .852,47$ & 5,10 \\
\hline
\end{tabular}

Sumber: BPS Provinsi Sumatera Utara, 2016

Tabel 1 di atas menunjukkan angka impor Sumatera Utara selama 5 tahun terakhir yang semakin menurun dari tahun ke tahun, dengan angka tertinggi pada tahun 2012 dan terendah pada tahun 2015. Nilai impor yang semakin berkurang menunjukkan menurunnya ketergantungan negara kita terhadap produk-produk dari luar negeri. Sedangkan angka PDRB Sumatera Utara selama kurun waktu tersebut menunjukkan angka yang semakin tinggi dari tahun ke tahun dari 2011 sampai dengan 2015. Laju pertumbuhan impor Sumatera Utara menunjukkan angka negatif sedangkan laju pertumbuhan PDRB Sumatera Utara menunjukkan angka yang positif. Keadaan ini berarti bahwa pendapatan daerah Provinsi Sumatera Utara semakin meningkat selama 5 tahun terakhir. Ini mencerminkan aktivitas ekonomi yang tinggi di Sumatera Utara pun melalui kegiatan perdagangan internasional ekspor dan impor. 


\section{KAJIAN TEORI}

Menurut Nopirin (1999) perdagangan internasional merupakan suatu hubungan antara satu negara dengan negara lain dalam bentuk hubungan ekonomi seperti jual beli barang dan jasa maupun uang dengan tujuan memperoleh keuntungan (gain) dan untuk menjalin kerjasama di bidang internasional. Terjadinya perdagangan internasional antara satu negara dengan negara lainnya dapat mendorong kerja sama yang lebih erat antar sesama negara di dunia. Sehingga dengan adanya perdagangan luar negeri dapat menguntungkan antar negara satu sama lainnya, baik di bidang ekonomi maupun bidang sosial lainnya.

Produk Domestik Bruto (PDB) adalah penghitungan yang digunakan oleh suatu negara sebagai ukuran utama bagi aktivitas perekonomian nasionalnya, tetapi pada dasarnya PDB mengukur seluruh volume produksi dari suatu wilayah (negara) secara geografis. Dan penghitungan yang digunakan oleh suatu daerah seperti provinsi/kabupaten/kota sebagai ukuran utama bagi aktivitas perekonomian daerahnya disebut dengan Poroduk Domestik Regional Bruto (PDRB).

Menurut Pasaribu (2013) impor merupakan perdagangan memasukkan barang dari luar negeri ke wilayah pabeanan suatu negara dengan memenuhi ketentuan yang berlaku. Impor sering dilakukan sebagai alternatif kebijakan memenuhi kebutuhan dalam negeri atas suatu barang apabila produksi domestik akan barang tersebut tidak memadai. Impor suatu negara ditentukan oleh beberapa faktor diantaranya daya saing negara tersebut dan kurs valuta asing. Namun penentu impor yang utama adalah pendapatan masyarakat suatu negara. Namun, impor tidak selalu dipengaruhi oleh pendapatan saja namun turut dipengaruhi faktor lain yang berkaitan dengan keseimbangan permintaan dan penawaran yang terjadi, misalnya perubahan faktor-faktor lain seperti kebijakan perdagangan internasional pada negara pengimpor, kebijakan perdagangan internasional pada negara pengekspor, inflasi, ekspor negara lain serta faktor lain yang terkait yang dapat menggeser fungsi impor.

Inflasi adalah kecenderungan terjadinya kenaikan harga-harga umum secara terus menerus. Kenaikan harga dari satu atau dua barang saja tidak dapat disebut sebagai inflasi, kecuali bila kenaikan tersebut meluas kepada (mengakibatkan kenaikan) sebagian besar dari harga barang-barang lain. Kenaikan harga-harga disebabkan oleh faktor-faktor musiman (misalnya menjelang peringatan hari-hari besar), atau yang terjadi sekali saja (dan tidak mempunyai pengaruh lanjutan) tidak disebut inflasi (Case dan Fair, 2004).

Kurs atau nilai tukar merupakan salah satu faktor yang menentukan arus perdagangan internasional. Tingkat kurs mata uang adalah harga dari mata uang sebuah negara dilihat dari segi mata uang negara lain. Kurs merupakan rasio dimana dua mata uang saling dipertukarkan (Case dan Fair, 2004).

Terdapat hubungan keseimbangan dalam jangka pendek dan jangka panjang antara PDRB Sumatera Utara, Inflasi Sumatera Utara dan Kurs Rupiah terhadap Dolar AS terhadap Impor Sumatera Utara.

\section{METODE PENELITIAN}

Penelitian ini dilakukan di Indonesia. Kurun waktu penelitian mulai dari tahun 19902015. Dan estimasi data menggunakan software EViews v.9.0. Rincian data yang digunakan dan sumber data yang dibutuhkan dalam penelitian ini adalah sebagai berikut. 
Published Desember 2017

EKONOMIKAWAN : Jurnal Ilmu Ekonomi dan Studi Pembangunan

ISSN : 1693-7600 (Print), ISSN : 2598-0157 (Online), http://jurnal.umsu.ac.id/index.php/ekawan

Tabel 2

Sumber Data Sekunder

\begin{tabular}{|l|l|}
\hline \multicolumn{1}{|c|}{ Data yang digunakan } & \multicolumn{1}{c|}{ Sumber data sekunder } \\
\hline $\begin{array}{l}\text { Impor Provinsi Sumatera Utara } \\
\text { menurut Negara Asal Utama (000 } \\
\text { US\$) }\end{array}$ & $\begin{array}{l}\text { BPS Provinsi Sumatera Utara } \\
\text { Atau http://sumut.bps.go.id/ }\end{array}$ \\
\hline $\begin{array}{l}\text { PDRB Sumatera Utara } \\
\text { (Juta Rupiah) }\end{array}$ & $\begin{array}{l}\text { BPS Provinsi Sumatera Utara } \\
\text { Atau http://sumut.bps.go.id/ }\end{array}$ \\
\hline $\begin{array}{l}\text { Inflasi Sumatera Utara } \\
(\%)\end{array}$ & $\begin{array}{l}\text { BPS Provinsi Sumatera Utara } \\
\text { atau http://sumut.bps.go.id/ }\end{array}$ \\
\hline $\begin{array}{l}\text { Kurs rupiah terhadap dolar AS } \\
\text { (US\$/Rp) }\end{array}$ & $\begin{array}{l}\text { Bank Indonesia } \\
\text { Atau http://bi.go.id/ }\end{array}$ \\
\hline $\begin{array}{l}\text { Keadaan Impor Provinsi Sumatera } \\
\text { Utara di pasar dunia }\end{array}$ & Majalah, Artikel, Internet, Jurnal Ilmiah \\
\hline
\end{tabular}

Persamaan identitas dalam penelitian ini dengan model ekonometrika disesuaikan dengan penambahan intercept dan error disturbance term :

$$
Y_{t}=\beta_{0}+\beta_{1} X_{1 t}+\beta_{2} X_{2 t}+\beta_{3} X_{3 t}+e_{t}
$$

dimana:

$\begin{array}{lll}\mathrm{Y} & = & \text { Impor Provinsi Sumatera Utara } \\ \beta_{0} & = & \text { intersep/konstanta } \\ \mathrm{X}_{1} & = & \text { PDRB Sumatera Utara } \\ \mathrm{X}_{2} & = & \text { Inflasi Sumatera Utara } \\ \mathrm{X}_{3} & = & \text { Kurs Rupiah terhadap Dolar AS } \\ \beta_{1}, \beta_{2}, \beta_{3} & = & \text { koefisien/parameter } \\ \mathrm{e} & = & \text { error term/error disturbance term } \\ \mathrm{t} & = & \text { unsur waktu }\end{array}$

Dalam penelitian ini, estimasi hubungan antar variabel dilakukan melalui beberapa tahapan, yakni Uji Akar-Akar Unit (Unit Roots Test), Uji Kausalitas (Causality Test), Uji Asumsi Klasik, Uji Kointegrasi (Cointegration Test), Error Correction Mechanism/ECM dan Estimasi Jangka Panjang.

\section{HASIL DAN PEMBAHASAN}

\section{Uji Akar-Akar Unit (Unit Roots Test)}

Berikut adalah hasil uji stasioner menggunakan uji akar unit Augmented DickeyFuller (ADF) dari masing-masing data variabel dalam penelitian ini. 


\section{Tabel 3}

Hasil Estimasi Pengujian ADF Unit Root Test

\begin{tabular}{|l|c|c|c|}
\hline \multicolumn{1}{|c|}{ Variabel } & $\begin{array}{c}\text { ADF } \\
\text { test statistic }\end{array}$ & Prob. & Stasioner pada \\
\hline D(IMPOR_SUMUT) & $-5,325040$ & 0,0002 & $1^{\text {st }}$ difference \\
\hline D(PDRB_SUMUT,2) & $-6,135957$ & 0,0000 & $2^{\text {nd }}$ difference \\
\hline D(KURS) & $-4,722487$ & 0,0010 & $1^{\text {st }}$ difference \\
\hline INFLASI & $-5,164769$ & 0,0003 & level \\
\hline
\end{tabular}

Sumber : data diolah, (2017)

Berdasarkan Tabel, hasil uji akar unit pada variabel Impor Sumatera Utara (Y) pada $I^{\text {st }}$ difference menunjukkan probabilitas $<\alpha=0,05$. Pada variabel PDRB Sumatera Utara $\left(\mathrm{X}_{1}\right)$ pada $2^{\text {nd }}$ difference menunjukkan probabilitas $<\alpha=0,05$. Pada variabel Kurs rupiah terhadap Dolar AS $\left(\mathrm{X}_{3}\right)$ pada $I^{\text {st }}$ difference menunjukkan probabilitas $<0,05$. Dan pada variabel Inflasi $\left(\mathrm{X}_{2}\right)$ pada level menunjukkan probabilitas $<\alpha=0,05$. Sehingga dapat disimpulkan dalam model estimasi koreksi kesalahan dalam jangka pendek (ECM) menggunakan variabel stasioner pada $l^{\text {st }}$ difference.

\section{Uji Kausalitas (Causality Test)}

Uji kausalitas berguna untuk melihat hubungan satu atau dua arah antar variabel penelitian. Uji kausalitas dalam penelitian ini dengan menggunakan metode Granger Causality Test. Hasil penelitian uji kausalitas tersebut dapat dilihat pada Tabel 4 berikut ini :

\section{Tabel 4}

Hasil Estimasi Uji Kausalitas Granger Causality Test

\begin{tabular}{|l|c|c|c|}
\hline Null Hypothesis: & Obs & $\begin{array}{c}\text { F- } \\
\text { Statistic }\end{array}$ & Prob. \\
\hline PDRB_SUMUT does not Granger Cause IMPOR_SUMUT & 24 & $\begin{array}{c}1,46660 \\
\text { IMPOR_SUMUT does not Granger Cause PDRB_SUMUT }\end{array}$ & 0,2557 \\
\hline KURS does not Granger Cause IMPOR_SUMUT & 24 & 0,37931 & 0,6894 \\
IMPOR_SUMUT does not Granger Cause KURS & & 0,61728 & 0,5499 \\
\hline INFLASI does not Granger Cause IMPOR_SUMUT & 24 & 0,15643 & 0,8563 \\
IMPOR_SUMUT does not Granger Cause INFLASI & & 0,64426 & 0,5361 \\
\hline KURS does not Granger Cause PDRB_SUMUT & 24 & 0,16858 & 0,8461 \\
PDRB_SUMUT does not Granger Cause KURS & & 1,45317 & 0,2587 \\
\hline INFLASI does not Granger Cause PDRB_SUMUT & 24 & 0,07979 & 0,9236 \\
PDRB_SUMUT does not Granger Cause INFLASI & & 0,76819 & 0,4777 \\
\hline INFLASI does not Granger Cause KURS & 24 & 3,66282 & 0,0451 \\
KURS does not Granger Cause INFLASI & & 3,60347 & 0,0471 \\
\hline
\end{tabular}

Sumber : data diolah, 2017 
Published Desember 2017

EKONOMIKAWAN : Jurnal Ilmu Ekonomi dan Studi Pembangunan

ISSN : 1693-7600 (Print), ISSN : 2598-0157 (Online), http://jurnal.umsu.ac.id/index.php/ekawan

Berdasarkan Tabel di atas, hasil uji kausalitas antara variabel Impor Sumatera Utara (Y), PDRB Sumatera Utara $\left(\mathrm{X}_{1}\right)$, Kurs $\left(\mathrm{X}_{2}\right)$ dan Inflasi $\left(\mathrm{X}_{3}\right)$ dapat dijelaskan sebagai berikut :

1) Hubungan kausalitas antara PDRB Sumatera Ekspor $\left(X_{1}\right)$ dan Impor Sumatera Utara (Y) menunjukkan bahwa hipotesis nol yang menyatakan PDRB_SUMUT does not Granger Cause IMPOR_SUMUT tidak ditolak karena tingkat signifikansinya 25,57 persen. Dan hipotesis nol yang menyatakan IMPOR_SUMUT does not Granger Cause PDRB_SUMUT juga tidak ditolak karena tingkat signifikansinya 45,48 persen. Hal ini berarti antara PRDB Sumatera Utara dan Impor Sumatera Utara memiliki hubungan yang dua arah.

2) Hubungan kausalitas antara Impor Sumatera Utara $(\mathrm{Y})$ dan $\operatorname{Kurs}\left(\mathrm{X}_{2}\right)$ menunjukkan bahwa hipotesis nol yang menyatakan KURS does not Granger Cause IMPOR_SUMUT tidak ditolak karena tingkat signifikansinya 68,94 persen. Dan hipotesis nol yang menyatakan IMPOR_SUMUT does not Granger Cause KURS juga tidak ditolak karena tingkat signifikansinya 54,99 persen. Hal ini berarti antara Impor Sumatera Utara dan Kurs rupiah terhadap Dolar AS memiliki hubungan yang dua arah.

3) Hubungan kausalitas antara Impor Sumatera Utara (Y) dan Inflasi $\left(\mathrm{X}_{3}\right)$ menunjukkan bahwa hipotesis nol yang menyatakan INFLASI does not Granger Cause IMPOR_SUMUT tidak ditolak karena tingkat signifikansinya 85,63 persen. Dan hipotesis nol yang menyatakan IMPOR_SUMUT does not Granger Cause INFLASI juga tidak ditolak karena tingkat signifikansinya 53,61 persen. Hal ini berarti antara Impor Sumatera Utara dan Inflasi memiliki hubungan yang dua arah.

4) Hubungan kausalitas antara PDRB Sumatera Utara $\left(X_{1}\right)$ dan Kurs rupiah terhadap Dolar AS $\left(\mathrm{X}_{2}\right)$ menunjukkan bahwa hipotesis nol yang menyatakan KURS does not Granger Cause PDRB_SUMUT tidak ditolak karena tingkat signifikansinya 84,61 persen. Dan hipotesis nol yang menyatakan PDRB_SUMUT does not Granger Cause KURS juga tidak ditolak karena tingkat signifikansinya 25,87 persen. Hal ini berarti antara PDRB Sumatera Utara dan Kurs rupiah terhadap Dolar AS memiliki hubungan yang dua arah.

5) Hubungan kausalitas antara PDRB Sumatera Utara $\left(X_{1}\right)$ dan Inflasi $\left(X_{3}\right)$ menunjukkan bahwa hipotesis nol yang menyatakan INFLASI does not Granger Cause PDRB_SUMUT tidak ditolak karena tingkat signifikansinya 92,36 persen. Dan hipotesis nol yang menyatakan PDRB_SUMUT does not Granger Cause INFLASI juga tidak ditolak karena tingkat signifikansinya 47,77 persen. Hal ini berarti antara PDRB Sumatera Utara dan Inflasi memiliki hubungan yang dua arah.

\section{Uji Kointegrasi}

Uji kointegrasi berguna untuk melihat hubungan keseimbangan dalam jangka panjang antar variabel penelitian. Uji kointegrasi dalam penelitian ini dengan menggunakan metode Johansen Cointegration Test. Adapun hasil penelitian uji kointegrasi tersebut dapat dilihat pada Tabel berikut : 
Published Desember 2017

EKONOMIKAWAN : Jurnal Ilmu Ekonomi dan Studi Pembangunan

ISSN : 1693-7600 (Print), ISSN : 2598-0157 (Online), http://jurnal.umsu.ac.Id/index.php/ekawan

Tabel 5

Hasil Estimasi Uji Kointegrasi Johansen Cointegration Test

\begin{tabular}{|c|c|c|c|}
\hline Trace Statistic & $>$ & Critical Value & Prob. \\
& & 0,05 & \\
\hline 68,43701 & & 47,85613 & $0,0002<\alpha=0,05$ \\
\hline Max-Eigen Statistic & $>$ & Critical Value & Prob. \\
& & 0,05 & $0,0159<\alpha=0,05$ \\
\hline 27,86854 & & 27,58434 & \\
\hline
\end{tabular}

Sumber : data diolah, 2017

Berdasarkan Tabel, dapat dijelaskan bahwa nilai trace statistic adalah > nilai critical value dan nilai $p$-value adalah $<\alpha=0,05$. Nilai max-eigen statistic adalah $>$ nilai critical value dan nilai $p$-value adalah $<\alpha=0,05$. Ini berarti bahwa dalam jangka panjang terdapat kointegrasi pada model persamaan dalam penelitian ini.

\section{Pengujian Model Koreksi Kesalahan (Error Correction Mechanism)}

Menurut Pratomo dan Hidayat (2010), teknik untuk mengoreksi ketidakseimbangan jangka pendek menuju keseimbangan jangka panjang disebut dengan Error Correction Mechanism (ECM). Model ini pertama sekali digunakan oleh Sargan dan dipopulerkan oleh Engel dan Granger. Hasil model ECM dalam penelitian ini dapat dilihat pada Tabel berikut :

\section{Tabel 6}

\section{Hasil Estimasi Jangka Pendek}

\begin{tabular}{|c|c|c|c|c|}
\hline \multicolumn{5}{|c|}{ Dependent Variable: D(IMPOR_SU } \\
\hline \multicolumn{5}{|l|}{ Method: Least Squares } \\
\hline \multicolumn{5}{|c|}{ Sample (adjusted): 19912015} \\
\hline \multicolumn{5}{|c|}{ Included observations: 25 after adjustments } \\
\hline Variable & Coefficient & Std. Error & $\mathrm{t}$-Statistic & Prob. \\
\hline $\mathrm{C}$ & $-9,60 \mathrm{E}+11$ & $1,54 \mathrm{E}+12$ & $-0,621903$ & 0,5410 \\
\hline D(PDRB_SUMUT) & 133,9854 & 53,83360 & 2,488880 & 0,0217 \\
\hline D(KURS) & $1,04 \mathrm{E}+09$ & $1,27 \mathrm{E}+09$ & 0,819346 & 0,4222 \\
\hline D(INFLASI) & $-2,92 \mathrm{E}+10$ & $6,89 \mathrm{E}+10$ & $-0,423690$ & 0,6763 \\
\hline $\operatorname{RES}(-1)$ & $-0,745414$ & 0,281787 & $-2,645313$ & 0,0155 \\
\hline R-squared & 0,415875 & \multicolumn{2}{|c|}{ Mean dependent var } & $2,14 \mathrm{E}+12$ \\
\hline Adjusted R-squared & 0,299050 & \multicolumn{2}{|c|}{ S.D. dependent var } & $6,65 \mathrm{E}+12$ \\
\hline S.E. of regression & $5,57 \mathrm{E}+12$ & \multicolumn{2}{|c|}{ Akaike info criterion } & 61,71177 \\
\hline Sum squared resid & $6,21 E+26$ & \multicolumn{2}{|c|}{ Schwarz criterion } & 61,95555 \\
\hline Log likelihood & $-766,3971$ & \multicolumn{2}{|c|}{ Hannan-Quinn criter. } & 61,77938 \\
\hline F-statistic & 3,559812 & \multicolumn{2}{|c|}{ Durbin-Watson stat } & 1,447002 \\
\hline Prob(F-statistic) & 0,023856 & & & \\
\hline
\end{tabular}

Sumber : data diolah, 2017 
Berdasarkan Tabel hasil estimasi jangka pendek, dapat dilihat bahwa terjadi hubungan keseimbangan dalam jangka pendek yang ditunjukkan oleh nilai $p$-value variabel residual sebesar $0,0155<\alpha=0,05$. Terjadi hubungan keseimbangan jangka pendek antara variabel pdrb Sumatera Utara $\left(\mathrm{X}_{1}\right)$, Kurs rupiah terhadap Dolar AS $\left(\mathrm{X}_{2}\right)$ dan Inflasi $\left(\mathrm{X}_{3}\right)$ terhadap Impor Sumatera Utara (Y). Maka, model persamaan estimasi jangka pendek adalah seperti berikut.

\section{D $($ IMPOR_SUMUT $)=\mathbf{- 9 6 0 4 1 0 5 6 2 5 8 2}+\mathbf{1 3 3 , 9 9 * D}($ PDRB_SUMUT $)+$ $1042020237,7 * D(K U R S)-29177073889,8 * D(I N F L A S I)-$ 0,745414293986*RES(-1)}

Dari hasil estimasi model persamaan jangka pendek di atas dengan memasukkan variabel residual, diperoleh nilai koefisien determinasi $\left(R^{2}\right)$ sebesar 0,415875 atau 41,59 persen artinya bahwa variabel bebas dalam penelitian ini PDRB Sumatera Utara $\left(\mathrm{X}_{1}\right)$, Kurs rupiah terhadap Dolar AS $\left(\mathrm{X}_{2}\right)$ dan Inflasi $\left(\mathrm{X}_{3}\right)$ sebanyak 41,59 persen mempengaruhi variabel terikat Impor Sumatera Utara (Y) dan sisanya sebesar 58,41 persen dijelaskan oleh variabel lain di luar model penelitian, cateris paribus.

Jika PDRB Sumatera Utara $\left(\mathrm{X}_{1}\right)$, Kurs rupiah terhadap Dolar AS $\left(\mathrm{X}_{2}\right)$ dan Inflasi $\left(\mathrm{X}_{3}\right)$ bernilai 0 (nol) maka Impor Sumatera Utara (Y) akan menurun sebesar Rp 960.410.562.582 . Nilai koefisien PDRB Sumatera Utara $\left(\mathrm{X}_{1}\right)$ sebesar 133,99 artinya bahwa jika PDRB Sumatera Utara $\left(\mathrm{X}_{1}\right)$ naik sebesar Rp 1 maka Impor Sumatera Utara (Y) akan meningkat sebesar Rp 133,99. Nilai koefisien Kurs rupiah terhadap Dolar AS ( $\left.\mathrm{X}_{2}\right)$ sebesar 1042020237,7 artinya bahwa jika Kurs rupiah terhadap Dolar AS $\left(\mathrm{X}_{2}\right)$ terapresiasi sebesar 1 satuan maka Impor Sumatera Utara (Y) akan meningkat sebesar Rp 1042020237,7 . Dan nilai koefisien Inflasi $\left(X_{3}\right)$ sebesar -29177073889,8 artinya bahwa jika Inflasi meningkat sebesar 1 satuan maka Impor Sumatera Utara (Y) akan menurun sebesar Rp 29177073889,8, cateris paribus.

Dari hasil estimasi model persamaan jangka pendek di atas, diperoleh nilai t-statistik pada variabel PDRB Sumatera Utara $\left(\mathrm{X}_{1}\right)$ sebesar 2,488880 adalah $>$ nilai t-tabel sebesar 2,07387 dan nilai $p$-value sebesar 0,0217 adalah $<\alpha=0,05$ ini berarti bahwa variabel bebas PDRB Sumatera Utara $\left(\mathrm{X}_{1}\right)$ berpengaruh secara positif terhadap variabel terikat Impor Sumatera Utara (Y). PDRB Sumatera Utara signifikan mempengaruhi perubahan perkembangan Impor Sumatera Utara dalam jangka pendek, cateris paribus.

Dari hasil estimasi model persamaan jangka pendek di atas, diperoleh nilai t-statistik pada variabel Kurs rupiah terhadap Dolar AS $\left(\mathrm{X}_{2}\right)$ sebesar 0,819346 adalah < nilai t-tabel sebesar 2,07387 dan nilai $p$-value sebesar 0,4222 adalah $>\alpha=0,05$ ini berarti bahwa variabel bebas Kurs rupiah terhadap Dolar AS $\left(\mathrm{X}_{2}\right)$ tidak berpengaruh secara positif terhadap variabel terikat Impor Sumatera Utara (Y). Kurs rupiah terhadap Dolar AS tidak signifikan mempengaruhi perubahan perkembangan Impor Sumatera Utara dalam jangka pendek, cateris paribus. 
Dari hasil estimasi model persamaan jangka pendek di atas, diperoleh nilai t-statistik pada variabel Inflasi $\left(\mathrm{X}_{3}\right)$ sebesar $-0,423690$ adalah < nilai t-tabel sebesar 2,07387 dan nilai $p$-value sebesar 0,6763 adalah $>\alpha=0,05$ ini berarti bahwa variabel bebas Inflasi $\left(\mathrm{X}_{3}\right)$ tidak berpengaruh secara positif terhadap variabel terikat Impor Sumatera Utara (Y). Inflasi tidak signifikan mempengaruhi perubahan perkembangan Impor Sumatera Utara dalam jangka pendek, cateris paribus.

Dari hasil estimasi model persamaan jangka pendek di atas, diperoleh nilai F-statistik sebesar 3,559812 adalah > F-tabel sebesar 3,050 dan nilai $p$-value sebesar 0,023856< $\alpha=$ 0,05 ini berarti bahwa secara bersama-sama PDRB Sumatera Utara $\left(\mathrm{X}_{1}\right)$, Kurs rupiah terhadap Dolar AS $\left(\mathrm{X}_{2}\right)$ dan Inflasi $\left(\mathrm{X}_{3}\right)$ positif dan signifikan mempengaruhi perubahan perkembangan Impor Sumatera Utara $(\mathrm{Y})$, cateris paribus.

\section{Analisis Jangka Panjang}

Setelah diketahui bahwa terdapat kointegrasi, maka tahap selanjutnya adalah dengan melakukan estimasi persamaan model untuk jangka panjang. Ini dilakukan dengan uji regresi biasa yang diturunkan dengan OLS (Ordinary Least Square) atau metode kuadran terkecil yang berguna untuk melihat nilai koefisien/parameter masing-masing variabel bebas terhadap variabel terikat, koefisien determinasi $\left(\mathrm{R}^{2}\right)$, uji t-statistic (parsial) dan uji Fstatistic (serempak). Berikut dapat dilihat hasil estimasi jangka panjang dalam penelitian ini.

\section{Tabel 7}

\section{Hasil Estimasi Jangka Panjang}

\begin{tabular}{|c|c|c|c|c|}
\hline \multicolumn{5}{|c|}{ Dependent Variable: LOG(IMPOR_SUMUT) } \\
\hline \multicolumn{5}{|l|}{ Method: Least Squares } \\
\hline \multicolumn{5}{|l|}{ Sample: 19902015} \\
\hline \multicolumn{5}{|l|}{ Included observations: 26} \\
\hline Variable & Coefficient & Std. Error & t-Statistic & Prob. \\
\hline $\mathrm{C}$ & 2,996625 & 1,593053 & 1,881059 & 0,0733 \\
\hline LOG(PDRB_SUMUT) & 1,192685 & 0,117959 & 10,11097 & 0,0000 \\
\hline LOG(KURS) & $-0,368032$ & 0,203078 & $-1,812271$ & 0,0836 \\
\hline LOG(INFLASI) & 0,018857 & 0,091016 & 0,207188 & 0,8378 \\
\hline R-squared & 0,958790 & \multicolumn{2}{|c|}{ Mean dependent var } & 29,85077 \\
\hline Adjusted R-squared & 0,953171 & \multicolumn{2}{|c|}{ S.D. dependent var } & 1,270058 \\
\hline S.E. of regression & 0,274841 & \multicolumn{2}{|c|}{ Akaike info criterion } & 0,395390 \\
\hline Sum squared resid & 1,661826 & \multicolumn{2}{|c|}{ Schwarz criterion } & 0,588943 \\
\hline Log likelihood & $-1,140067$ & \multicolumn{2}{|c|}{ Hannan-Quinn criter. } & 0,451126 \\
\hline F-statistic & 180,6186 & \multicolumn{2}{|c|}{ Durbin-Watson stat } & 1,426569 \\
\hline Prob(F-statistic) & 0,000000 & & & \\
\hline
\end{tabular}

Sumber : data diolah, 2017 
Berdasarkan Tabel di atas, model persamaan jangka panjang dalam penelitian ini dapat dijelaskan seperti berikut :

\section{LOG $($ IMPOR_SUMUT $)=2,9966+1,1927 *$ LOG $($ PDRB_SUMUT $)$ -$$
\text { 0,3680*LOG(KURS) + 0,0189*LOG(INFLASI) }
$$

Dari hasil estimasi model persamaan jangka panjang di atas dengan menggunakan logaritma, diperoleh nilai koefisien determinasi $\left(\mathrm{R}^{2}\right)$ sebesar 0,958790 atau 95,88 persen artinya bahwa variabel bebas dalam penelitian ini pdrb Sumatera Utara $\left(\mathrm{X}_{1}\right)$, Kurs rupiah terhadap Dolar AS $\left(\mathrm{X}_{2}\right)$ dan Inflasi $\left(\mathrm{X}_{3}\right)$ sebanyak 95,88 persen mempengaruhi variabel terikat Impor Sumatera Utara (Y) dan sisanya sebesar 4,12 persen dijelaskan oleh variabel lain di luar model, cateris paribus.

Jika PDRB Sumatera Utara $\left(\mathrm{X}_{1}\right)$, Kurs rupiah terhadap Dolar AS $\left(\mathrm{X}_{2}\right)$ dan Inflasi $\left(\mathrm{X}_{3}\right)$ bernilai 0 (nol) maka Impor Sumatera Utara (Y) akan meningkat sebesar 2,9966 persen. Nilai koefisien PDRB Sumatera Utara $\left(X_{1}\right)$ sebesar 1,1927 artinya bahwa jika PDRB Sumatera Utara $\left(\mathrm{X}_{1}\right)$ naik sebesar 1 persen maka Impor Sumatera Utara (Y) akan meningkat sebesar 1,1927 persen. Nilai koefisien Kurs rupiah terhadap Dolar AS $\left(\mathrm{X}_{2}\right)$ sebesar -0,3680 artinya bahwa jika Kurs rupiah terhadap Dolar AS $\left(\mathrm{X}_{2}\right)$ terapresiasi sebesar 1 persen maka Impor Sumatera Utara (Y) akan menurun sebesar 0,3680 persen. Dan nilai koefisien Inflasi $\left(\mathrm{X}_{3}\right)$ sebesar 0,0189 artinya bahwa jika inflasi naik sebesar 1 persen maka Impor Sumatera Utara (Y) akan meningkat sebesar 0,0189, cateris paribus.

Dari hasil estimasi model persamaan jangka panjang di atas, diperoleh nilai t-statistik pada variabel PDRB Sumatera Utara $\left(\mathrm{X}_{1}\right)$ sebesar 10,11097 adalah > nilai t-tabel sebesar 2,07387 dan nilai $p$-value sebesar 0,0000 adalah $<\alpha=0,05$ ini berarti bahwa variabel bebas PDRB Sumatera Utara $\left(\mathrm{X}_{1}\right)$ berpengaruh secara positif terhadap variabel terikat Impor Sumatera Utara (Y). PDRB Sumatera Utara mempengaruhi perubahan perkembangan Impor Sumatera Utara dalam jangka panjang, cateris paribus.

Dari hasil estimasi model persamaan jangka panjang di atas, diperoleh nilai t-statistik pada variabel Kurs rupiah terhadap Dolar AS $\left(\mathrm{X}_{2}\right)$ sebesar -1,812271 adalah < nilai t-tabel sebesar 2,07387 dan nilai $p$-value sebesar 0,0836 adalah $>\alpha=0,05$ ini berarti bahwa variabel bebas Kurs rupiah terhadap Dolar AS $\left(\mathrm{X}_{2}\right)$ berpengaruh negatif terhadap variabel terikat Impor Sumatera Utara (Y). Kurs rupiah terhadap Dolar AS tidak signifikan mempengaruhi perubahan perkembangan Impor Sumatera Utara dalam jangka panjang, cateris paribus.

Dari hasil estimasi model persamaan jangka panjang di atas, diperoleh nilai t-statistik pada variabel Inflasi $\left(\mathrm{X}_{3}\right)$ sebesar 0,207188 adalah < nilai t-tabel sebesar 2,07387 dan nilai $p$-value sebesar 0,8378 adalah $>\alpha=0,05$ ini berarti bahwa variabel bebas Inflasi $\left(\mathrm{X}_{3}\right)$ tidak berpengaruh secara positif terhadap variabel terikat Impor Sumatera Utara (Y). Inflasi tidak signifikan mempengaruhi perubahan perkembangan Impor Sumatera Utara dalam jangka panjang, cateris paribus. 
Dari hasil estimasi model persamaan jangka panjang di atas, diperoleh nilai Fstatistik sebesar 170,6186 adalah > F-tabel sebesar 3,050 dan nilai p-value sebesar $0,000000<\alpha=0,05$ ini berarti bahwa secara bersama-sama PDRB Sumatera Utara $\left(\mathrm{X}_{1}\right)$, Kurs rupiah terhadap Dolar AS $\left(\mathrm{X}_{2}\right)$ dan Inflasi $\left(\mathrm{X}_{3}\right)$ secara positif dan signifikan mempengaruhi perubahan perkembangan Impor Sumatera Utara (Y), cateris paribus.

Berdasarkan hasil penelitian dan penjelasan di atas, variabel PDRB Sumatera Utara $\left(\mathrm{X}_{1}\right)$, Kurs rupiah terhadap Dolar AS $\left(\mathrm{X}_{2}\right)$ dan Inflasi $\left(\mathrm{X}_{3}\right)$ masing-masing memiliki nilai pengaruh yang berbeda-beda dalam jangka panjang maupun jangka pendek terhadap Impor Sumatera Utara (Y). Sehingga hasil penelitian tersebut di atas dapat dirangkum dengan menggunakan Tabel berikut.

\section{Tabel 8}

\section{Hasil Estimasi Persamaan Jangka Panjang dan Jangka Pendek}

\begin{tabular}{|l|l|l|}
\hline \multicolumn{1}{|c|}{ Variabel } & \multicolumn{1}{|c|}{$\begin{array}{c}\text { Pengaruh } \\
\text { Jangka Panjang }\end{array}$} & \multicolumn{1}{c|}{$\begin{array}{c}\text { Pengaruh } \\
\text { Jangka Pendek }\end{array}$} \\
\hline $\begin{array}{l}\text { PDRB Sumatera } \\
\text { Utara }\left(\mathrm{X}_{1}\right)\end{array}$ & $\begin{array}{l}\text { Berpengaruh positif dan } \\
\text { signifikan sebesar 1,192685 }\end{array}$ & $\begin{array}{l}\text { Berpengaruh positif dan } \\
\text { signifikan sebesar 133,9854 }\end{array}$ \\
\hline Kurs $\left(\mathrm{X}_{2}\right)$ & $\begin{array}{l}\text { Berpengaruh negatif dan tidak } \\
\text { signifikan sebesar 0,368032 }\end{array}$ & $\begin{array}{l}\text { Berpengaruh positif dan tidak } \\
\text { signifikan sebesar } \\
1042020237,7\end{array}$ \\
\hline Inflasi $\left(\mathrm{X}_{3}\right)$ & $\begin{array}{l}\text { Berpengaruh positif dan tidak } \\
\text { signifikan sebesar 0,018857 }\end{array}$ & $\begin{array}{l}\text { Berpengaruh negatif dan tidak } \\
\text { signifikan sebesar - } \\
\text { 29177073889,8 }\end{array}$ \\
\hline
\end{tabular}

Sumber : Tabel 5 dan 6 ; data diolah, 2017 ; dimana $Y=$ Ekspor ke Singapura

Berdasarkan Tabel di atas, dapat dijelaskan bahwa variabel PDRB Sumatera Utara $\left(\mathrm{X}_{1}\right)$ adalah berpengaruh positif dan signifikan terhadap Impor Sumatera Utara (Y) dalam jangka pendek maupun jangka panjang. Kurs rupiah terhadap Dolar AS $\left(\mathrm{X}_{2}\right)$ berpengaruh negatif dan tidak signifikan dalam jangka panjang, berpengaruh positif dan tidak signifikan dalam jangka pendek terhadap Impor Sumatera Utara $(\mathrm{Y})$. Dan inflasi $\left(\mathrm{X}_{3}\right)$ berpengaruh positif dan tidak signifikan dalam jangka panjang, berpengaruh negatif dan tidak signifikan dalam jangka pendek, cateris paribus.

Provinsi Sumatera Utara merupakan provinsi yang terletak di belahan Utara pulau Sumatera berdasarkan letak geografis Indonesia. Sumatera Utara adalah provinsi terbesar utama di pulau Sumatera dengan ibukota provinsi Medan. Provinsi ini juga dikenal sebagai provinsi penghubung daerah ekonomi antara Aceh dan provinsi di pulau Sumatera lainnya. Baik merupakan jalur perdagangan pendistribusian barang-barang industri antar daerah di Sumatera. Dengan demikian provinsi Sumatera Utara tergolong provinsi yang maju sebab memiliki kawasan industri selain sumber daya alam yang melimpah. 
Published Desember 2017

EKONOMIKAWAN : Jurnal Ilmu Ekonomi dan Studi Pembangunan

ISSN : 1693-7600 (Print), ISSN : 2598-0157 (Online), http://jurnal.umsu.ac.Id/index.php/ekawan

Namun demikian tidak halnya membuat Sumatera Utara dapat berdiri sendiri dalam memenuhi kebutuhan penduduknya sebab kegiatan ekonomi juga didukung proses pemindahan barang-barang ataupun jasa dari satu tempat ke tempat lainnya demi mendapatkan barang-barang ataupun jasa dalam pemenuhan kebutuhan ekonomi penduduk setempat yang pada akhirnya dapat menambah pendapatan daerah. Selain perdagangan antar daerah, Sumatera Utara juga melakukan perdagangan luar negeri dengan memiliki beberapa negara sebagai mitra dagang. Salah satunya yakni impor barang-barang berkebutuhan sesuai daftar barang-barang impor per periode satuan waktu.

Berdasarkan teori, kegiatan impor yang dilakukan sebab barang tidak dapat dihasilkan di dalam negeri sendiri pun sebagai alasan bahwasanya apabila diproduksi sendiri memakan waktu yang lama juga biaya produksi yang besar. Alasan inilah yang mendorong Sumatera Utara memiliki angka impor terhadap barang terdaftar tertentu demi pemenuhan kebutuhan penduduk setempat. Impor tetap membawa keuntungan dari sisi ekonomi melalui keuntungan terhadap nilai jual barang-barang impor diasumsikan jumlah angka barang-barang impor tidak melebihi jumlah angka barang-barang ekspor.

Hasil penelitian uji kausalitas diketahui PDRB Sumatera Utara dan Impor Sumatera Utara memiliki hubungan kausalitas dua arah yakni PDRB Sumatera Utara ke Impor Sumatera Utara dan sebaliknya Impor Sumatera Utara ke PDRB Sumatera Utara. Dengan demikian perubahan PDRB Sumatera Utara menyebabkan perubahan Impor Sumatera Utara dan begitu pula sebaliknya perubahan Impor Sumatera Utara menyebabkan perubahan PDRB Sumatera Utara. Artinya bahwa jika nilai PDRB Sumatera Utara mengalami peningkatan maka hal tersebut akan membawa perubahan peningkatan pada Impor Sumatera Utara pula yang tercermin pada kemampuan daya beli provinsi Sumatera Utara dalam memenuhi kebutuhan barang-barang impor.

Berdasarkan hasil penelitian, PDRB Sumatera Utara secara positif dan signifikan mempengaruhi perubahan perkembangan Impor Sumatera Utara dalam jangka pendek dan jangka panjang kurun waktu 1990 sampai dengan 2015. Hal ini menandakan bahwa jika PDRB Sumatera Utara meningkat akan mempengaruhi peningkatan Impor Sumatera Utara pula selama kurun waktu 1990 sampai dengan 2015. Dan jika PDRB Sumatera Utara menurun akan mempengaruhi penurunan Impor Sumatera Utara pula selama kurun waktu 1990 sampai dengan 2015.

Pendapatan daerah atau pendapatan negara riil secara signifikan mempengaruhi impor sesuai dengan penelitian terdahulu oleh Jamil (2015). Ini mencerminkan kemampuan daya beli suatu daerah pada kebutuhan barang-barang impor. Keterbatasan potensi suatu daerah dalam menghasilkan barang-barang ekonomi menjadi pendorong dalam kegiatan perdagangan internasional melalui impor. Impor barang-barang ekonomi tidak sepenuhnya membawa kerugian dalam perekonomian jika nilainya tidak melebihi impor. 
Pemerintah melalui kebijakan perdagangan internasionalnya tetap memberlakukan quota atau batasan impor terhadap barang-barang yang masih bisa diproduksi di dalam negeri, dengan tujuan melindungi industr-industri baru di dalam negeri. Begitu halnya dengan provinsi Sumatera Utara, hanya pada daftar barang tertentu saja yang dilakukan impor demi mendukung lancarnya kegiatan produksi barang-barang ekonomi berdasarkan kategori yang menunjukkan angka permintaan tinggi.

\section{KESIMPULAN}

PDRB Sumatera Utara dan Impor Sumatera Utara memiliki hubungan kausalitas dua arah yakni PDRB Sumatera Utara ke Impor Sumatera Utara dan sebaliknya Impor Sumatera Utara ke PDRB Sumatera Utara. Dengan demikian perubahan PDRB Sumatera Utara menyebabkan perubahan Impor Sumatera Utara dan begitu pula sebaliknya perubahan Impor Sumatera Utara menyebabkan perubahan PDRB Sumatera Utara. Artinya bahwa jika nilai PDRB Sumatera Utara mengalami peningkatan maka hal tersebut akan membawa perubahan peningkatan pada Impor Sumatera Utara pula yang tercermin pada kemampuan daya beli provinsi Sumatera Utara dalam memenuhi kebutuhan barang-barang impor.

PDRB Sumatera Utara secara positif dan signifikan mempengaruhi perubahan perkembangan Impor Sumatera Utara dalam jangka pendek dan jangka panjang kurun waktu 1990 sampai dengan 2015. Hal ini menandakan bahwa jika PDRB Sumatera Utara meningkat akan mempengaruhi peningkatan Impor Sumatera Utara pula selama kurun waktu 1990 sampai dengan 2015. Dan jika PDRB Sumatera Utara menurun akan mempengaruhi penurunan Impor Sumatera Utara pula selama kurun waktu 1990 sampai dengan 2015.

Kepada pemerintah melalui kementrian perindustrian dan perdagangan terus memantau, mengkoordinasi dan melakukan sinkronisasi data terhadap kebutuhan barangbarang impor dengan tujuan tetap mengendalikan angka impor (batasan/quota impor) dalam negeri pun di provinsi Sumatera Utara.

\section{DAFTAR PUSTAKA}

Ajija, Shochrul. R, dkk. 2011. Cara Cerdas Menguasai EViews. Salemba Empat . Jakarta. Atmadji, Eko. 2004. Analisis Impor Indonesia. Jurnal Ilmiah. Jurnal Ekonomi Pembangunan Vol. 9 No. 1 . Fakultas Ekonomi Universitas Islam Indonesia. Yogyakarta.

Badan Pusat Statistik. 2016. Sumatera Utara Dalam Angka 2016. Badan Pusat Statistik Provinsi Sumatera Utara . Medan.

Bank Indonesia. 2016. Kurs/Exchange Rate Periode 1990-2015. Bank Indonesia . Jakarta.

Case dan Fair. 2004. Prinsip-Prinsip Ekonomi Makro. Penerbit Indeks Kelompok Gramedia . Jakarta. 
Published Desember 2017

EKONOMIKAWAN : Jurnal IImu Ekonomi dan Studi Pembangunan

ISSN : 1693-7600 (Print), ISSN : 2598-0157 (Online), http://jurnal.umsu.ac.Id/index.php/ekawan

Hidayat, Paidi. 2010. Analisis Kausalitas dan Kointegrasi Antara Jumlah Uang Beredar, Inflasi dan Pertumbuhan Ekonomi di Indonesia. Jurnal Ekonom, Vol. 13 No. 1, Januari 2010.

Macroeconomics Dashboard. 2017. Mengenal Istilah HS, SITC, CIF, FOB. dari http://macroeconomicdashboard.feb.ugm.ac.id/ [diakeses pada tanggal 10 Juli 2017]

McEachern, Willian A. 2009. A Contemporary Introduction, $8^{\text {th }}$ Edition. South Western. Cengage Learning.

Nopirin. 1999. Ekonomi Internasional. BPFE Universitas Gadjah Mada. Yogyakarta.

Pasaribu, Theresia Wediana dan Daulay Murni. 2013. Analisis Permintaan Impor Bawang Merah di Indonesia. Jurnal Ilmiah. Jurnal Ekonomi dan Keuangan Vol. 1, No. 4 , Februari 2013. Universitas Sumatera Utara. Medan.

Rangkuty, Dewi M. 2017. Analisis Kausalitas dan Kointegrasi Antara Inflasi dan Ekspor Indonesia ke Singapura Periode 1990-2015. Jurnal Ilmiah. Universitas Pembangunan Panca Budi. Medan.

Salvatore, Dominick. 1997. Ekonomi Internasional. Salemba Empat . Jakarta. .2007. International Economics $9^{\text {th }}$ Edition. Wiley and Sons Inc.

Jakarta.

. 2014. Ekonomi Internasional Edisi 9 Buku 1. Salemba Empat.

Shyh-Wei, Chen. 2007. Exactly what is the link between export and growth in Taiwan.

Economics Bulletin, Vol. 6. No. 7 pp, 1-10. 